\section{Use of radiographic images for rapid and non-destructive assessment of crambe seed quality}

\author{
Alessandra da Silva Ribeiro ${ }^{1}$ iD, Tássia Fernanda Santos Neri ${ }^{1}{ }^{(i D}$, André Dantas $^{2}$ \\ de Medeiros ${ }^{1}$ (D), Carla do Carmo Milagres ${ }^{1^{*}}$ (D), Laércio Junio da Silva ${ }^{1}$ (iD
}

ABSTRACT: Technologies based on electromagnetic radiation, such as the X-ray technique, has contributed to the establishment of new and promising methodologies for evaluating seed quality. This study aimed to relate parameters based on semi-automated analysis of radiographs of crambe seeds to their physiological quality. Radiographic images of seeds from 10 seed lots of cultivar FMS Brilhante were semi-automatically analyzed using Image ${ }^{\circ}$ software. Measurements of morphometric characteristics and tissue integrity were obtained for the seeds, as well as individually for the seed embryo. Following X-ray test, the seeds were subject to germination and seedling growth test. It was possible to visualize the internal structures of the seeds in the radiographs. There were differences in the physical parameters obtained by the semi-automated analysis of the radiographs between the seed lots. Also, the lots differed regarding the physiological quality of the seeds. Morphometric characteristics and tissue integrity, especially for the seed embryo, showed high correlation with the seed physiological quality. Therefore, this work presents an efficient approach to rapid and non-destructively assess the quality of crambe seeds.

Index terms: Crambe abyssinica, image analysis, relative density, seed radiography.

\section{Uso de imagens radiográficas para avaliação rápida e não destrutiva da qualidade de sementes de crambe}

RESUMO: Tecnologias baseadas em radiação eletromagnética, como a técnica de raios $X$, contribuíram para estabelecer novas e promissoras metodologias para avaliar a qualidade de sementes. Nesse sentido, este estudo teve como objetivo relacionar parâmetros baseados na análise semiautomatizada de radiografias de sementes de crambe à sua qualidade fisiológica. Imagens radiográficas de sementes pertencentes a 10 lotes da cultivar FMS Brilhante foram analisadas de forma semiautomatizada por meio do software Image ${ }^{\circ}$. Foram obtidas medidas de características morfométricas e integridade tecidual das sementes, bem como individualmente para o embrião das sementes. Após o teste de raio- $X$, as sementes foram submetidas ao teste de germinação e crescimento de plântulas. Foi possível visualizar as estruturas internas das sementes nas radiografias. Houve diferenças nos parâmetros físicos obtidos pela análise semiautomática das radiografias entre os lotes de sementes. Além disso, os lotes diferiram quanto à qualidade fisiológica das sementes. Características morfométricas e de integridade tecidual, especialmente para o embrião, apresentaram alta correlação com a qualidade fisiológica. Assim, este trabalho apresenta uma abordagem eficiente para avaliar de forma rápida e não destrutiva a qualidade de sementes de crambe.

Termos para indexação: Crambe abyssinica, análise de imagem, densidade relativa, radiografia de sementes.
Journal of Seed Science, v.43, e202143001, 2021

http://dx.doi.org/10.1590/ 2317-1545v43239136 


\section{INTRODUCTION}

The crambe (Crambe abyssinica Hochst) is a winter crop belonging to the Brassicaceae family, originating in the Mediterranean and found in several tropical and subtropical areas (Martins et al., 2017). The species has been recognized as a good raw material option for biodiesel production and has been recommended for use in the offseason of annual crops, such as soybean, as it has a short cycle and high tolerance to drought (Falasca et al., 2010).

To maximize the productivity potential of the crop, one of the main requirements is satisfactory establishment of plant population in the field, which requires the use of seeds with high physiological quality (Leão et al., 2016). For crambe, germination and vigor tests, such as electrical conductivity, accelerated aging, cold test and seedling length measurements have been used to classify seed lots in terms of quality, serving as support for decision making in the seed industry (Soares et al., 2018; Machado et al., 2017; Silva et al., 2016).

Following technological advances, new methodologies allowing quicker and more precise responses regarding aspects of seed quality are being developed. The use of X-ray electromagnetic radiation stands out for evaluating the internal seed morphology. This technique allows investigation of morphological and structural abnormalities of the seed internal tissues and their causes (Arruda et al., 2016). The X-ray test is based on differential absorption of X-rays by the tissues; the denser and thicker the tissue, the lighter the image generated (Kotwaliwale et al., 2014). This test can be used for seeds of several species without causing damage to the seeds, as is used low doses of radiation, enabling evaluation of internal structures that otherwise would be difficult to evaluate (Xia et al., 2019).

Based on the images generated, several parameters can be obtained from the radiograph which can be correlated with results of other tests, such as germination and vigor tests, facilitating the classification of seed lots regarding seed physiological quality (Medeiros et al., 2018). For this purpose, specific software is used, simply and non-destructively, to measure the pixel density (mean pixel values in a monochromatic image - ranging from 0 , black, to 255 , white), free internal space and other characteristics that can often be related to the physiological quality of the seeds (Abud et al., 2018; Medeiros et al., 2018).

However, there is still no information demonstrating the efficiency of X-ray testing to evaluate internal morphological characteristics and their relationship with the physiological quality of crambe seeds. This information would be useful for optimizing the industry internal quality control during seed production which, together with the use of modern computational techniques to evaluate the radiographs generated, would confer greater speed and precision on these evaluations. Moreover, improvement of this technique has great potential to be adjusted and used for other species, signifying great advances in the field of seed production technology.

Therefore, this study aimed to propose a semi-automated method for analyzing radiographic images of crambe seeds and to relate the parameters obtained to their physiological quality.

\section{MATERIAL AND METHODS}

\section{Seed samples and internal morphology analysis}

Ten crambe seed lots of cultivar FMS Brilhante differing in the physiological quality were used. The seeds were produced at the Unidade de Pesquisa e Extensão Vale da Agronomia, of the Universidade Federal de Viçosa, Viçosa, Minas Gerais, Brazil (20 45'30.7"S and 42 $52^{\prime} 15.8^{\prime \prime} \mathrm{W}$, altitude $684 \mathrm{~m}$ ), between the years 2012 and 2016.

The moisture content of the seeds was determined using the oven method at $105 \pm 3^{\circ} \mathrm{C}$ for 24 hours (Brasil, 2009). Two replicates of $2 \mathrm{~g}$ of seeds were used for each lot.

For the analysis of internal morphology, four replicates of 50 seeds were used, initially organized and spread on adhesive paper, properly identified with the lot number and the position of each seed. After this step, the seeds were subject to $X$-ray electromagnetic radiation. The equipment used to generate the digital radiographic images was the Faxitron, model MX-20 (Faxitron X-ray Corp. Wheeling, IL, USA), adjusted for 10 seconds of radiation, with a voltage of 
$23 \mathrm{kV}$, focal length of $41.6 \mathrm{~cm}$, and image contrast of 13917 (width) x 5374 (center).

In this study, the fruit of the crambe was referred to as the seed, which is the term used commercially, and the botanical seed was called the embryo, as the tegument is thin and not very representative in relation to the embryonic axis and cotyledons, which are the structures occupying almost the totality of the seed.

\section{Semi-automated analysis of radiographies}

Digital radiographs were analyzed using Image $J^{\circ}$ software, following the semi-automated methodology proposed by Medeiros et al. (2018). The individual seeds and embryos on the radiographic images were manually selected, using the in-built Image ${ }^{\circ}$ 'Wand Tool'. Following, it was run the automated 'Analyze Particle'. The variables area $\left(\mathrm{mm}^{2}\right)$, perimeter $(\mathrm{mm})$, circularity, solidity, relative density (gray pixel-1) and integrated density (gray $\mathrm{mm}^{2}$ pixel $^{-1}$ ) were determined for the commercial seed and the embryo, as well as the percentage of seed filling (Table 1).

\section{Seed physiological quality}

After obtaining the X-ray images, the seeds were subjected to the germination test. The same seeds were used, arranged in the same way used to obtain the radiographs, in order to relate the physiological evaluations with the image data individually for each seed. To perform the germination test, plastic transparent boxes $(11 \times 11 \times 3 \mathrm{~cm})$ were used, with two germitest paper sheets on the bottom, which were moistened with distilled water, in the proportion of 2.5 times the dry paper mass. The set was stored at $25^{\circ} \mathrm{C}$ in a germinator. Daily counts of germinated seed were taken until the seventh day after sowing (Brasil, 2009). With this data, the following variables were obtained: percentage of radicle protrusion (radicle greater than $2 \mathrm{~mm}$ ), percentage of germination (seedlings with length exceeding $20 \mathrm{~mm}$, with roots and cotyledons visible and with normal development), mean germination time, mean radicle protrusion time, germination speed index, radicle protrusion speed index, $\mathrm{T}_{50}$ (time to reach $50 \%$ germination) and synchrony index. The indices were calculated using the SeedCalc R package, and the equations are described in Silva et al. (2019).

At the end of the germination test, the seedlings and the non-germinated seeds were scanned. The images were used to manually measure the length of hypocotyl, primary root and total seedling length using the Image ${ }^{\circ}$ software. The length data were processed using the SeedCalc R package (Silva et al., 2019) and the following indexes were generated: seedling growth, uniformity, vigor (Sako et al., 2001) and corrected vigor (Medeiros and Pereira, 2018).

Table 1. Parameters evaluated in the semi-automated analysis of radiographic images of Crambe abyssinica seeds.

\begin{tabular}{|c|c|c|c|}
\hline \multicolumn{2}{|c|}{ Structure } & \multirow{2}{*}{ Characteristic } & \multirow{2}{*}{ Description } \\
\hline Seed & Embryo & & \\
\hline AreaSeed & AreaEmb & Area $\left(\mathrm{mm}^{2}\right)$ & Area of the seed or embryo. \\
\hline PerSeed & PerEmb & Perimeter $(\mathrm{mm})$ & $\begin{array}{l}\text { Perimeter of the seed or embryo - the outline of each } \\
\text { seed in the image. }\end{array}$ \\
\hline CircSeed & CircEmb & Circularity & $\begin{array}{l}\text { Seed or embryo circularity - the shape of the seed being } \\
1 \text {, completely roundly, and } 0 \text {, not roundly. }\end{array}$ \\
\hline RelDensSeed & RelDensEmb & $\begin{array}{l}\text { Relative Density } \\
\text { (gray.pixel }^{-1} \text { ) }\end{array}$ & $\begin{array}{l}\text { Mean gray in the seed or embryo - the mean value of } \\
\text { each pixel comprising the seed in a monochromatic } \\
\text { image, ranging from } 0 \text { (black) to } 255 \text { (white). }\end{array}$ \\
\hline IntDenSeed & IntDenEmb & $\begin{array}{l}\text { Integrated density } \\
\text { (gray. } \mathrm{mm}^{2} \text {. pixel }{ }^{-1} \text { ) }\end{array}$ & $\begin{array}{l}\text { Product of the area of the seed or embryo with the } \\
\text { relative density. }\end{array}$ \\
\hline SolSeed & SolEmb & Solidity & $\begin{array}{l}\text { Relation between area and convex area. Regular } \\
\text { shape }=1 \text {, irregular shape }<1 .\end{array}$ \\
\hline \multicolumn{2}{|c|}{ Filling } & Seed Filling & $\begin{array}{l}\text { Percentage of area of the embryo in relation to the area } \\
\text { of the seed }(\%) \text {. }\end{array}$ \\
\hline
\end{tabular}




\section{Experimental design and data analysis}

The experiment was conducted in a completely randomized design with four replicates. The data were subjected to analysis of variance, following verification of the normality assumptions and homogeneity of variances, using the Shapiro-Wilk and Bartlett tests, respectively. The means obtained for the lots were grouped using the Scott-Knott test $(p<0.05)$ and then subjected to Pearson's correlation analysis. The significance of the correlation was evaluated using the T test $(p<0.05)$. Principal component analysis was performed using all parameters analyzed. Data analysis was performed using statistical software R 3.5.2 (R Core Team, 2019).

\section{RESULTS AND DISCUSSION}

The moisture content of the seeds from all the lots were considered close, ranging from 9.2 to $10.8 \%$, and there was no significant difference between the lots. These data are important, as significant differences in seed moisture content may compromise the accuracy of the results, since it affects the quality of the images generated in the X-ray test (Simak, 1991).

In this research, the moisture content of the seeds enabled good visualization of the seeds' internal morphology (Figure 1). It was possible to visualize the main structures of the seeds and differentiate well-formed and malformed seeds, as well as seeds without embryo (Figure 1A). Furthermore, it was possible to identify differences in tissue density within each seed, represented by a color gradient generated using each pixel gray value (Figure 1C). However, it was not possible to visualize the embryonic axis precisely.

In studies using X-ray to analyze seeds of other species, such as sesame (Nogueira Filho et al., 2017) and cashew (Silva et al., 2017), the internal structures of the seeds could be seen, while the water content varied between 6.5 and $12 \%$. Thus, the water content of the crambe seeds used in this study did not reduce the quality of the images generated. However, as mentioned in the previous studies, the oil content of the seeds influences the detailing of the internal structures visualized in the images, which often makes it impossible to identify important tissues, such as the

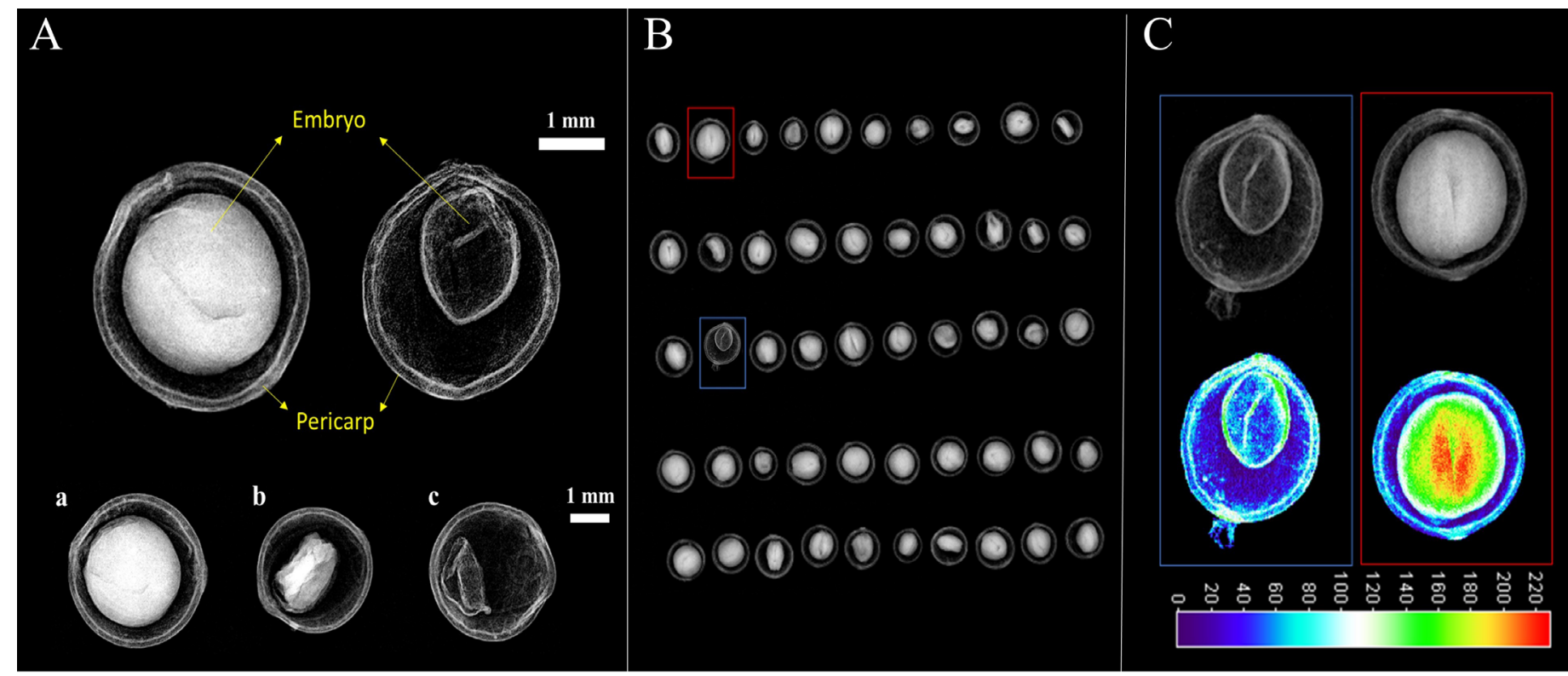

A: seed internal structures, in which (a) is a well-formed seed, (b) is a malformed seed, and (c) is a seed without embryo. The main structures visualized (pericarp and embryo) are indicated.

B: full image acquired for semiautomated analysis showing the seed arrangement.

C: two seeds highlighted with contrasting tissue densities (the colors represent the gray value).

Figure 1. Radiographic images of Crambe abyssinica seeds. 
embryonic axis. Thus, it is emphasized that crambe seeds have high oil content ranging from 36 to $38 \%$ which, together with its round shape, may have impaired visualization of the internal structures in greater detail.

The mean seed area ranged from 6.61 to $7.82 \mathrm{~mm}^{2}$ between the lots for complete seed and from 3.05 to 3.84 $\mathrm{mm}^{2}$ for the embryo (Table 2). The perimeter, calculated based on the outline of each seed in the image, varied from 9.82 to $11.38 \mathrm{~mm}$ and from 7.69 to $8.52 \mathrm{~mm}$, for complete seed and embryo, respectively. Thus, it was observed significant differences in seed size between the lots. Lots 1 and 9 were those with the greatest values of perimeter and area, respectively.

Table 2. Physical parameters obtained by the semi-automated analysis of radiographic images of Crambe abyssinica seeds.

\begin{tabular}{|c|c|c|c|c|c|c|c|}
\hline Seed Lot & Area & Perimeter & Circularity & Relative density & Integrated density & Solidity & Seed filling \\
\hline Unit & $\mathrm{mm}^{2}$ & \multicolumn{2}{|c|}{$\mathrm{mm}$} & gray.pixel ${ }^{-1}$ & gray.mm². pixel $^{-1}$ & & \\
\hline \multicolumn{8}{|c|}{ Seed } \\
\hline 1 & $7.37 \mathrm{~b}^{\mathrm{a}}$ & $11.38 \mathrm{a}$ & $0.75 \mathrm{~b}$ & $89.32 \mathrm{c}$ & $664 \mathrm{~b}$ & $0.976 \mathrm{c}$ & $50.07 a$ \\
\hline 2 & $6.70 \mathrm{~d}$ & $9.90 \mathrm{c}$ & $0.86 a$ & $94.16 \mathrm{~b}$ & $631 b$ & $0.983 b$ & $51.42 \mathrm{a}$ \\
\hline 3 & $6.61 \mathrm{~d}$ & $9.82 \mathrm{c}$ & $0.86 a$ & $98.03 \mathrm{a}$ & $648 b$ & $0.983 b$ & $52.47 \mathrm{a}$ \\
\hline 4 & $7.23 \mathrm{~b}$ & $10.20 \mathrm{~b}$ & $0.87 a$ & $87.22 \mathrm{c}$ & $632 b$ & $0.984 \mathrm{a}$ & $42.24 \mathrm{c}$ \\
\hline 5 & $6.96 \mathrm{c}$ & $10.18 b$ & $0.85 a$ & 99.95 a & $697 a$ & $0.982 b$ & $51.02 \mathrm{a}$ \\
\hline 6 & $7.06 \mathrm{c}$ & $10.25 b$ & $0.85 a$ & $100.72 \mathrm{a}$ & $710 \mathrm{a}$ & $0.983 b$ & $52.12 \mathrm{a}$ \\
\hline 7 & $7.24 b$ & $10.42 \mathrm{~b}$ & $0.84 \mathrm{a}$ & $101.88 \mathrm{a}$ & $737 a$ & $0.982 b$ & $53.06 a$ \\
\hline 8 & $7.27 b$ & $10.30 \mathrm{~b}$ & $0.86 a$ & $101.52 \mathrm{a}$ & $738 a$ & $0.983 b$ & $52.33 \mathrm{a}$ \\
\hline 9 & $7.82 \mathrm{a}$ & $10.63 b$ & $0.87 a$ & $91.84 \mathrm{~b}$ & $718 \mathrm{a}$ & $0.984 \mathrm{a}$ & $45.28 b$ \\
\hline 10 & $7.16 \mathrm{~b}$ & $10.27 b$ & $0.85 a$ & $97.00 \mathrm{a}$ & $695 a$ & $0.983 b$ & $51.35 \mathrm{a}$ \\
\hline $\mathrm{Fc}$ & $8.65^{*}$ & $12.79 *$ & $26.69 *$ & $13.51^{*}$ & $10.76^{*}$ & $25.64 *$ & $32.49 *$ \\
\hline $\mathrm{CV}$ & 3.28 & 2.35 & 1.65 & 2.98 & 3.63 & 0.09 & 2.48 \\
\hline \multicolumn{8}{|c|}{ Embryo } \\
\hline 1 & $3.69 a$ & $8.21 \mathrm{a}$ & $0.69 a$ & $146.54 \mathrm{~b}$ & $549 \mathrm{~b}$ & $0.958 \mathrm{a}$ & - \\
\hline 2 & $3.44 \mathrm{~b}$ & $7.82 \mathrm{~b}$ & $0.71 \mathrm{a}$ & $147.65 b$ & $509 c$ & $0.960 \mathrm{a}$ & - \\
\hline 3 & $3.47 \mathrm{~b}$ & $7.69 \mathrm{~b}$ & $0.74 \mathrm{a}$ & $150.02 \mathrm{~b}$ & $522 c$ & $0.965 \mathrm{a}$ & - \\
\hline 4 & $3.05 c$ & $8.21 \mathrm{a}$ & $0.59 \mathrm{~b}$ & $144.71 \mathrm{~b}$ & $451 d$ & $0.927 b$ & - \\
\hline 5 & $3.55 b$ & $8.25 \mathrm{a}$ & $0.67 a$ & $154.30 \mathrm{a}$ & $549 \mathrm{~b}$ & $0.958 \mathrm{a}$ & - \\
\hline 6 & $3.68 \mathrm{a}$ & $8.24 \mathrm{a}$ & $0.69 a$ & $153.34 \mathrm{a}$ & $564 \mathrm{~b}$ & $0.963 \mathrm{a}$ & - \\
\hline 7 & $3.84 \mathrm{a}$ & $8.27 \mathrm{a}$ & $0.72 \mathrm{a}$ & $154.04 \mathrm{a}$ & 592 a & $0.966 \mathrm{a}$ & - \\
\hline 8 & $3.80 \mathrm{a}$ & $8.30 \mathrm{a}$ & $0.70 \mathrm{a}$ & $154.62 \mathrm{a}$ & $589 a$ & $0.965 \mathrm{a}$ & - \\
\hline 9 & $3.53 b$ & $8.53 a$ & $0.63 \mathrm{~b}$ & $147.03 \mathrm{~b}$ & $526 c$ & $0.948 a$ & - \\
\hline 10 & $3.67 \mathrm{a}$ & $8.27 \mathrm{a}$ & $0.69 a$ & $150.16 \mathrm{~b}$ & $553 \mathrm{~b}$ & $0.961 \mathrm{a}$ & - \\
\hline Fc & $17.03 *$ & $5.86^{*}$ & $9.89 *$ & $6.48^{*}$ & $24.62 *$ & $10.40 *$ & - \\
\hline $\mathrm{CV}$ & 3.07 & 2.45 & 4.07 & 1.88 & 3.07 & 0.76 & - \\
\hline
\end{tabular}

a: means followed by the same letter in the column were grouped together by the Scott-Knott test at the 0.05 probability level.

$*$ : significant by the $F$ test $(p<0.05)$.

Fc: calculated $F$ value.

$\mathrm{CV}$ : coefficient of variation. 
When comparing the complete seed, the lots showed low variability for circularity ( 0.75 to 0.87 ), a variable that indicates how rounded the seed is. Only the lot 1 differed from the others, presenting the lowest value (Table 2). However, when comparing only the embryo, lots 4 and 9 showed less rounded forms, i.e., lower values. Also, for a similar seed area, it is observed that the greater the circularity the smaller the perimeter, as observed in the seeds from lots 1 and 10.

According to Abud et al. (2018), studying broccoli seeds, the area of the seeds may reflect their vigor, since larger areas coincide with larger reserves available for seed germination and seedling growth. Marchi and Gomes Junior (2017) demonstrated that, for Senna multijuga seeds, it was the embryo area that most clearly expressed differences in the physiological quality of the lots in relation to the pericarp area. Likewise, larger values for embryo area were observed in lots 1, 6, 7, 8 and 10, indicative of the higher physiological quality of the seeds from these lots.

For the gray density parameters, relative density varied between lots. Three and two groups were formed, respectively, comparing the complete seed and the embryo. When considering the complete seed, tissue densities were low for lots 1 and 4, intermediate for lots 2 and 9, and high for the other lots, which is in agreement with the results obtained for the seeds' areas. As for the relative density of the embryo, lots 5, 6, 7 and 8 showed higher values, indicating higher tissue density of the seeds in these lots.

By means of the integrated density of the complete seed and the embryo, which considers the relative density and the area of the seeds, it was possible to classify the lots into two and four groups, respectively. Thus, it is evident that integrated density evaluated only in the tissues of the embryo can be promising for classifying the seeds at different levels of vigor, since the area of the embryo combined with analysis of the density of its tissue can be used to infer about the tissue integrity and the amount of reserve available for embryo growth.

In studies with broccoli (Abud, 2018) and leucaena (Medeiros et al., 2018) seeds, it was shown that the use of tissue density parameters obtained from radiographic images is promising and shows a strong correlation with the physiological quality of the seeds. Seeds with higher densities were classified as having greater vigor, which gave rise to normal, longer seedlings.

On the other hand, by means of the solidity, calculated based on the radius involving the area of the seed and its convex closure, it was possible to classify the lots into three and two groups, when comparing the complete seed and the embryo, respectively (Table 2). Lot 1 showed lower solidity, comparing whole seeds, while comparing only the embryo, lot 4 showed the lowest value.

In tissue engineering, curvature factors are useful for expressing capacity of cell space filling (or other structure being evaluated) and for evaluating the occurrence of concave or convex irregularities that can be used to perform an accurate analysis of the total area of the structure (Lobo et al., 2016). Solidity is a variable which can be used as a measure of density (Martinovic et al., 2018), in which values close to 1 correspond to a solid structure, while lower values reveal irregular limits, concavities (Soltys et al., 2005). Thus, for seeds with greater solidity, the difference between seed area and the seed convex area reduces, resulting in values of solidity close to 1 , which may indicate a well-formed seed without damage.

In addition, the seed filling, percentage of the area occupied by the embryo compared to the area of the seed, varied between seed lots. Lots 4 and 9 differed from each other, as well as from the other seed lots, showing the lowest percentages of embryo filling. This is an indication that the seeds from these lots have lower physiological quality, since the seed filling shows a close relationship with germination capacity, being a promising variable to distinguish lots with low physiological quality (Noronha et al., 2018; Silva et al., 2013).

Eight of the ten seed lots $(1,2,3,5,6,7,8,10)$ showed values of $60 \%$ or above for germination (normal seedlings) (Table 3). This is the minimum germination percentage required in the crambe seed trade in Brazil (Brasil, 2013). The radicular protrusion followed the same pattern observed for the germination data. However, the values obtained were higher as for this evaluation it was considered only the radicle protrusion ( $>2 \mathrm{~mm}$ ), which not necessarily culminate in the development of normal seedlings. 
Table 3. Physiological quality parameters of Crambe abyssinica seed lots.

\begin{tabular}{|c|c|c|c|c|c|c|c|c|}
\hline Seed Lot & Ger & RadProt & MGT & MRPT & $\mathrm{T}_{50}$ & GSI & RPSI & Sync. \\
\hline Unit & \multicolumn{2}{|c|}{$---\%---$} & \multicolumn{3}{|c|}{---- days ----} & \multicolumn{3}{|c|}{--- Index ---} \\
\hline 1 & $67 \mathrm{ba}$ & $83 b$ & 4.53 & $2.17 b$ & 3.94 & $7.71 b$ & $26.64 \mathrm{a}$ & $0.68 \mathrm{a}$ \\
\hline 2 & $78 \mathrm{~b}$ & $95 \mathrm{a}$ & 4.60 & $2.62 b$ & 3.97 & $8.67 b$ & $19.55 \mathrm{a}$ & $0.51 b$ \\
\hline 3 & $92 \mathrm{a}$ & 99 a & 4.23 & $2.41 \mathrm{~b}$ & 3.60 & $10.96 \mathrm{a}$ & $21.67 \mathrm{a}$ & $0.70 \mathrm{a}$ \\
\hline 4 & $26 d$ & $33 d$ & 4.86 & $3.61 \mathrm{a}$ & 4.17 & $2.77 \mathrm{~d}$ & $5.09 \mathrm{~b}$ & $0.33 \mathrm{~b}$ \\
\hline 5 & $90 \mathrm{a}$ & 99 a & 4.24 & $2.57 \mathrm{~b}$ & 3.64 & $10.75 \mathrm{a}$ & $20.66 \mathrm{a}$ & $0.70 \mathrm{a}$ \\
\hline 6 & $93 a$ & $99 \mathrm{a}$ & 4.27 & $2.55 \mathrm{~b}$ & 3.63 & $11.05 \mathrm{a}$ & $20.52 \mathrm{a}$ & $0.66 \mathrm{a}$ \\
\hline 7 & $86 a$ & $97 a$ & 4.35 & $2.55 \mathrm{~b}$ & 3.70 & $10.08 \mathrm{a}$ & $20.17 \mathrm{a}$ & $0.60 \mathrm{a}$ \\
\hline 8 & $90 \mathrm{a}$ & $100 \mathrm{a}$ & 4.44 & $2.82 \mathrm{~b}$ & 3.80 & $10.29 a$ & $18.86 \mathrm{a}$ & $0.50 \mathrm{~b}$ \\
\hline 9 & $48 c$ & $56 c$ & 4.67 & $3.46 \mathrm{a}$ & 3.99 & $5.28 \mathrm{c}$ & $9.19 \mathrm{~b}$ & $0.41 b$ \\
\hline 10 & $88 a$ & $93 a$ & 4.37 & $2.80 \mathrm{~b}$ & 3.77 & $10.15 \mathrm{a}$ & $17.88 \mathrm{a}$ & $0.54 \mathrm{~b}$ \\
\hline $\mathrm{Fc}$ & $27.93 *$ & $36.20^{*}$ & 1.91 & $4.70 *$ & 1.56 & $21.47^{*}$ & $7.97 *$ & $3.30 *$ \\
\hline $\mathrm{CV}$ & 11.22 & 8.92 & 6.74 & 15.13 & 7.94 & 13.64 & 24.64 & 25 \\
\hline
\end{tabular}

a: means followed by the same letter in the column were grouped together by the Scott-Knott test at the 0.05 probability.

$*$ : significant by the $\mathrm{F}$ test $(\mathrm{p}<0.05)$.

Fc: $F$ calculated.

$\mathrm{CV}$ : coefficient of variation.

Abbreviation: Final Germination (Ger), Radicle Protrusion (RadProt), Mean Germination Time (MGT), Mean Radicle Protrusion Time (MRPT), Mean time for 50\% germination (T50), Germination Speed Index (GSI), Radicle Protrusion Speed Index (RPSI), Synchrony of Germination (Sync).

For evaluations considering germination time, difference was observed between the lots only for the mean root protrusion time (MRPT). Lots 4 and 8 had higher values, 3.6 and 3.5 days, respectively. Lot differences were also observed for variables related to germination speed: germination speed index (GSI), radicle protrusion speed index (RPSI) and synchrony index (Sync). The lots were classified in four levels of vigor for GSI, in which the seeds from lots 3 , $5,6,7,8$ and 10 showed higher values, followed by lots 1 and 2 . By means of RPSI, it was possible to group the lots into just two levels of vigor. Lots 4 and 9 presented lower values, as it was observed in the germination test.

Soares et al. (2018) reported that GSI is a more sensitive parameter for detecting small differences in the physiological quality of seeds compared to RPSI. However, although seedlings are not evaluated to estimate RPSI, according to the seedling normality criteria adopted in seed technology, it is an important variable that can be used as an additional parameter to the germination test (Toledo et al., 2011). Thus, the crambe seed lots were classified in different levels of vigor regarding RPSI (Table 3).

Lots 1, 3, 5, 6, and 7 showed higher values of synchrony of germination (Table 3 ). This variable is related to the level of organization or disorder of the chemical reactions during the germination process and detects the number of times seed germination is observed, regardless of the time required. Synchronous values close to 1 mean that germination of all seeds occurred at the same time, while values close to 0 are observed when at least two seeds can germinate, one at a time (Ranal et al., 2009).

Seedlings from the different seed lots showed differences in growth (Table 4). In general, smaller values of length and vigor indexes were observed for the seedlings from seeds of lots 1, 4 and 9. Thus, for the other lots, seedlings with higher rates of development, growth and uniformity were observed, which may be related to the greater capacity of the seeds in transferring their reserves to the development of the embryonic axis (Finch-Savage and Bassel, 2016). These data reflect the higher vigor of the seeds of the lots $2,3,5,6,7,8$ and 10. 
Table 4. Morphological parameters of seedlings and quality indexes of Crambe abyssinica seed lots.

\begin{tabular}{cccccccc}
\hline Seed lots & Hypocotyl length & Root length & Seedling length & Uniformity & Growth & Vigor & Corrected vigor \\
\hline unit & \multicolumn{7}{c}{$----c m----$} \\
\hline 1 & $1.04 \mathrm{ba}$ & $0.93 \mathrm{~b}$ & $1.97 \mathrm{c}$ & $434 \mathrm{~b}$ & $94 \mathrm{~b}$ & $196 \mathrm{~b}$ & $135 \mathrm{~b}$ \\
2 & $1.72 \mathrm{a}$ & $2.43 \mathrm{a}$ & $4.15 \mathrm{a}$ & $576 \mathrm{a}$ & $236 \mathrm{a}$ & $338 \mathrm{a}$ & $267 \mathrm{a}$ \\
3 & $1.72 \mathrm{a}$ & $2.82 \mathrm{a}$ & $4.54 \mathrm{a}$ & $657 \mathrm{a}$ & $271 \mathrm{a}$ & $387 \mathrm{a}$ & $355 \mathrm{a}$ \\
4 & $0.90 \mathrm{~b}$ & $0.49 \mathrm{~b}$ & $1.39 \mathrm{c}$ & $267 \mathrm{c}$ & $53 \mathrm{~b}$ & $117 \mathrm{c}$ & $31 \mathrm{c}$ \\
5 & $1.95 \mathrm{a}$ & $2.75 \mathrm{a}$ & $4.70 \mathrm{a}$ & $615 \mathrm{a}$ & $267 \mathrm{a}$ & $372 \mathrm{a}$ & $336 \mathrm{a}$ \\
6 & $2.03 \mathrm{a}$ & $2.82 \mathrm{a}$ & $4.85 \mathrm{a}$ & $620 \mathrm{a}$ & $274 \mathrm{a}$ & $378 \mathrm{a}$ & $352 \mathrm{a}$ \\
7 & $1.76 \mathrm{a}$ & $2.76 \mathrm{a}$ & $4.51 \mathrm{a}$ & $579 \mathrm{a}$ & $266 \mathrm{a}$ & $360 \mathrm{a}$ & $313 \mathrm{a}$ \\
8 & $1.90 \mathrm{a}$ & $2.69 \mathrm{a}$ & $4.59 \mathrm{a}$ & $632 \mathrm{a}$ & $261 \mathrm{a}$ & $373 \mathrm{a}$ & $336 \mathrm{a}$ \\
9 & $1.74 \mathrm{a}$ & $1.28 \mathrm{~b}$ & $3.01 \mathrm{~b}$ & $444 \mathrm{~b}$ & $132 \mathrm{~b}$ & $226 \mathrm{~b}$ & $111 \mathrm{~b}$ \\
10 & $1.84 \mathrm{a}$ & $2.55 \mathrm{a}$ & $4.39 \mathrm{a}$ & $665 \mathrm{a}$ & $248 \mathrm{a}$ & $373 \mathrm{a}$ & $326 \mathrm{a}$ \\
\hline Fc & $13.24^{*}$ & $7.56^{*}$ & $10.14^{*}$ & $16.23^{*}$ & $7.90^{*}$ & $15.09 *$ & $16.28^{*}$ \\
CV & 12.54 & 30.17 & 20.43 & 11.56 & 28.32 & 15.82 & 22.91 \\
\hline
\end{tabular}

${ }^{a}$ : means followed by the same letter in the column were grouped together by the Scott-Knott test at the 0.05 probability level.

$*$ :significant by the $\mathrm{F}$ test $(\mathrm{p}<0.05)$.

Fc: calculated $\mathrm{F}$ value.

CV: coefficient of variation.

Growth, uniformity, vigor and corrected vigor indexes were consistent for evaluating the physiological quality of crambe seeds (Table 4). Thus, these indices are recommended for evaluating the physiological quality of seeds of this species. Previous research has also shown excellent results in identifying vigor differences between seed lots with the use of at least one of these indices in cultivated species such as maize (Castan et al., 2018), soybean (Medeiros and Pereira, 2018).

The parameters area, circularity, solidity, perimeter and integrated density of the whole seed showed low efficiency in indicating seed vigor, and low values of correlation with the physiological quality data (Figure 2). However, all parameters evaluated on the embryo, except PerEmb, showed strong correlations with the variables related to germination and seedling length.

The other parameters generated based on analysis of the radiographs, with emphasis on the relative density of both the seed and the embryo, showed high correlation with physiological characterization parameters (e.g. Ger: $r=0.87, r=$ 0.79; RadProt: $r=0.81, r=0.73$; GSI: $r=0.87, r=0.80$; CorVigor: $r=0.92, r=0.82$; respectively). The seed filling and embryo solidity parameters were also related to the seed quality, showing high correlations ( $r>0.90)$ with the percentage of seed germination, seedling uniformity and other variables related to physiological attributes. This result indicates that semiautomated analysis of X-ray radiographs is efficient to infer about the germination and vigor of the seeds.

The results obtained in the present study (Figure 3) show the adaptation of the methodology of X-ray image analysis for crambe seeds. The use of free access tools to evaluate characteristics of the seed internal morphology enabled to evaluate parameters related to their physiological quality. Abud et al. (2018) also found significant and positive correlations between the mean gray density values of seed radiographs and shape descriptors (area and circularity) with the length of broccoli seedlings, suggesting that these parameters can be used to evaluate the physiological quality of the seeds. Thus, the approach used in the present study performing the analysis of the images with the Image $^{\circ}$ software has additional advantages, such as greater speed in obtaining the data, greater reliability and precision of the results. The use of Image ${ }^{\circ}$ software for analyzing seed radiographs of other species has been reported, as for Solanum gilo (Prado-alves et al., 2018), Brassica oleraceae (Abud et al., 2018), Leucaena leucocephala (Medeiros et al., 2018), Moringa oleifera (Noronha et al., 2018) and Acca sellowiana (Silva et al., 2013). 


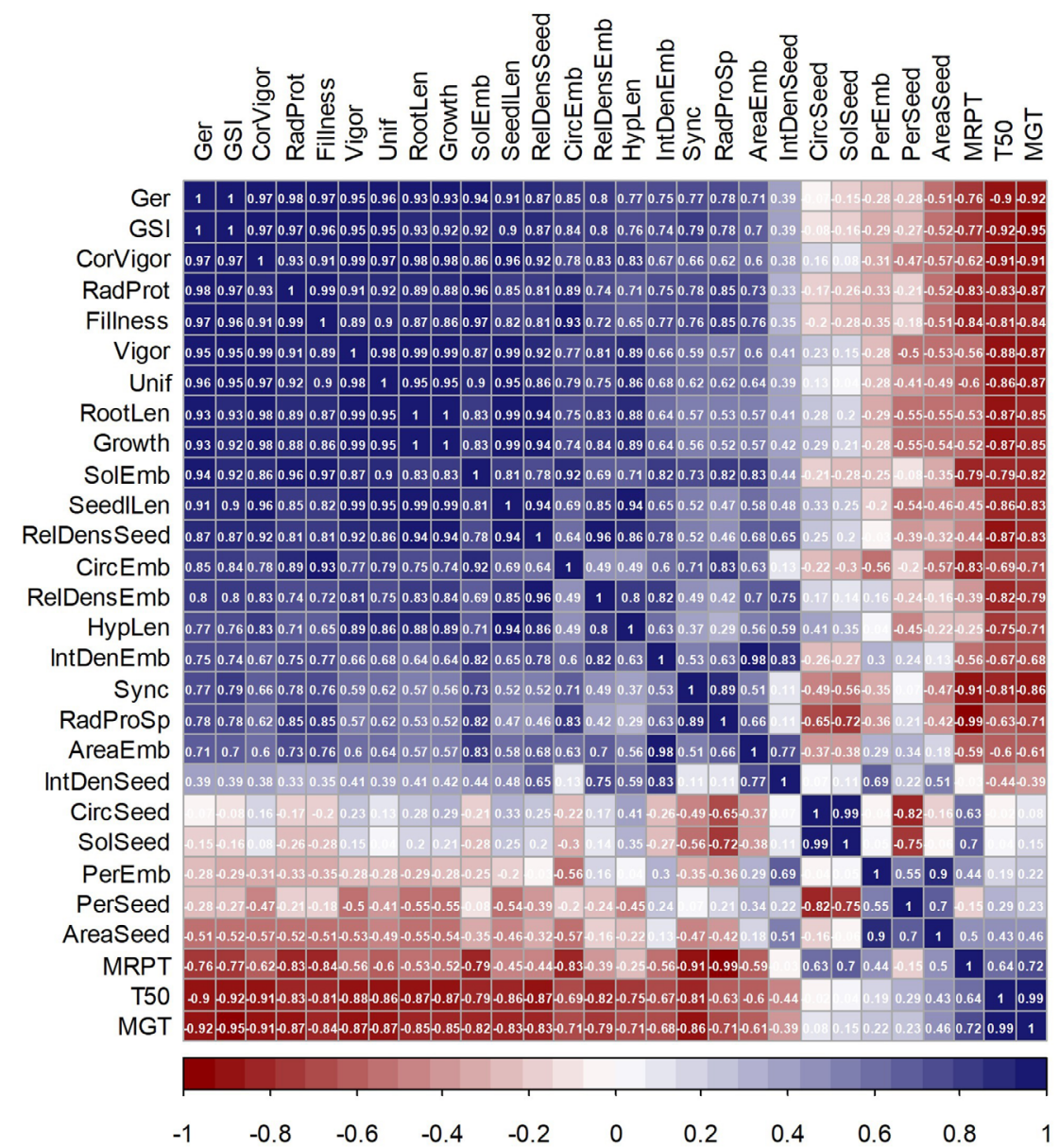

Figure 2. Pearson's correlation ( $r$ ) between the parameters generated by the semiautomated analysis of the radiographic imagens and by the germination and seedling growth tests of Crambe abyssinica seed lots.

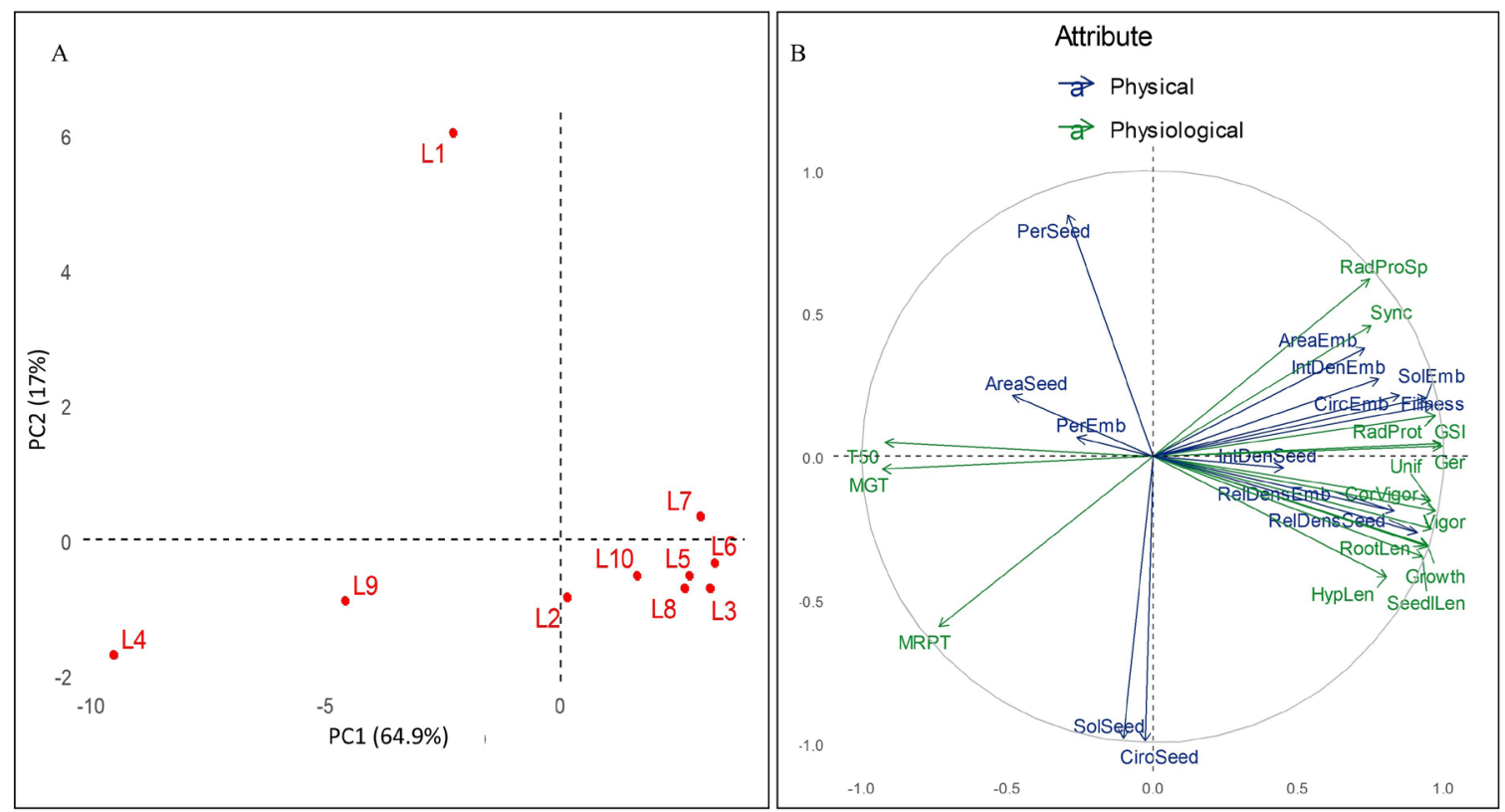

Figure 3. Biplot of the parameters related to the physical (radiographic image analysis) and physiological (seed germination and seedling growth) characteristics of Crambe abyssinica seed lots. 
The first two components of the principal component analysis (PCA) explained $81.9 \%$ of the total data variability (Figure 3). The vectors comprising characteristics related to germination and seedling performance were close to the variables obtained in the semi-automated analysis of radiographic images of the seeds and embryos, indicating high correlation between the characteristics, as was also observed for the correlation data (Figure 2). It is also observed that lots 1, 4 and 9 were distant and in a position opposite to the vectors related to seedling length and density parameters of the embryo. This indicates that for these variables, these lots had lower values, i.e., seeds from these lots had lower physiological quality. These data agreed with those obtained for evaluating seed germination and vigor (Tables 3 and 4).

PCA is a multivariate technique which remains little explored for seed quality data. These associations found by PCA can be efficient in determining seed quality. Moreover, the results can be easily understood and interpreted (Abud et al., 2018; Medeiros et al., 2018), especially when dealing with a large number of seed lots undergoing several tests to assess seed vigor.

Relative density of seed (RelDensSeed) and embryo (RelDensEmb), integrated density of embryo (IntDenEmb) and percentage of seed filling, obtained analyzing the X-ray images, showed high significant correlation with the seed physiological quality (Figures 2 and 3). Thus, the integration between semi-automated X-ray image analysis, obtaining parameters associated with physical characteristics related to the physiological quality, is an efficient approach to rapid and non-destructively assess the quality of crambe seeds.

Although promising, this methodology does not eliminate the necessity of performing physiological tests, as a dead seed could present high tissue density. But it has great potential to be used in quality control programs to discard low quality seed lots, whose seeds will present low values of gray in the images.

\section{CONCLUSIONS}

Semi-automated analysis of radiographic images allows the evaluation of the internal morphology of crambe seeds, and to obtain physical parameters related to the physiological quality of the seeds.

\section{ACKNOWLEDGEMENTS}

This study was financed in part by the Coordenação de Aperfeiçoamento de Pessoal de Nível Superior - Brasil (CAPES) - Finance Code 001.

\section{REFERENCES}

ABUD, H.F.; CICERO, S.M.; GOMES-JUNIOR, F.G. Radiographic images and relationship of the internal morphology and physiological potential of broccoli seeds. Acta Scientiarum, v.40, p.e34950, 2018. https://doi.org/10.4025/actasciagron.v40i1.34950

ARRUDA, N.; CICERO, S.M.; GOMES-JUNIOR, F.G. Radiographic analysis to assess the seed structure of Crotalaria juncea L. Journal of Seed Science, v.38, n.2, p.161-168, 2016. https://doi.org/10.1590/2317-1545v38n2155116

BRASIL. Ministério da Agricultura, Pecuária e Abastecimento. Regras para análise de sementes. Ministério da Agricultura, Pecuária e Abastecimento. Secretaria de Defesa Agropecuária. Brasília: MAPA/ACS, 2009. 395p. https://www.gov.br/agricultura/pt-br/ assuntos/insumos-agropecuarios/arquivos-publicacoes-insumos/2946_regras_analise_sementes.pdf

BRASIL. Portaria SDA no 16, de 25 de janeiro de 2013. Projeto de Instrução Normativa e Anexos que aprovam normas e padrões de identidade e de qualidade para produção e comercialização de sementes das espécies de gramíneas (Poaceae) forrageiras, espécies de leguminosas (Fabaceae) forrageiras e outras espécies de forrageiras. Diário Oficial da União, Brasília, 28 de janeiro de 2013. Seção 1. https://www.in.gov.br/materia/-/asset_publisher/KujrwOTZC2Mb/content/id/30034279/do1-2013-01-28-portaria-n-16de-25-de-janeiro-de-2013-30034267

CASTAN, D.O.C.; GOMES-JUNIOR, F.G.; MARCOS-FILHO, J. Vigor-S, a new system for evaluating the physiological potential of maize seeds. Scientia Agricola, v.75, n.2, p.167-172, 2018. https://doi.org/10.1590/1678-992x-2016-0401 
FALASCA, S.L.; FLORES, N.; LAMAS, M.C.; CARBALLO, S.M.; ANSCHAU, A. Crambe abyssinica: an almost unknown crop with a promissory future to produce biodiesel in Argentina. International Journal of Hydrogen Energy, v.35, n.11, p.5808-5812, 2010. https://doi.org/10.1016/j.ijhydene.2010.02.095

FINCH-SAVAGE, W.E.; BASSEL, G.W. Seed vigour and crop establishment: extending performance beyond adaptation. Journal of Experimental Botany, v.67, n.3, p.567-591, 2016. https://doi.org/10.1093/jxb/erv490

KOTWALIWALE, N.; SINGH, K.; KALNE, A.; JHA, S.N.; SETH, N.; KAR, A. X-ray imaging methods for internal quality evaluation of agricultural produce. Journal of Food Science and Technology, v.51, n.1, p.1-15, 2014. https://doi.org/10.1007/s13197-011-0485-y

LEÃO, É.F.; SANTOS, J.F.; BARBOSA, R.M.; VIEIRA, R.D. Accelerated ageing as a vigour test for crambe (Crambe abyssinica) seeds. Australian Journal of Crop Science, v.10, n.5, p.660-665, 2016. https://doi.org/10.21475/ajcs.2016.10.05.p7359

LOBO, J.; SEE, E.Y.S.; BIGGS, M.; PANDIT, A. An insight into morphometric descriptors of cell shape that pertain to regenerative medicine. Journal of Tissue Engineering and Regenerative Medicine, v.10, n.7, p.539-553, 2016. https://pubmed.ncbi.nlm.nih. gov/25757807/

MACHADO, F.H.B.; DAVID, A.M.S.S.; CANGUSSÚ, L.V.S.; FIGUEIREDO, J.C.; AMARO, H.T.R. Physiological quality of seed and seedling performance of crambe genotypes under water stress. Revista Brasileira de Engenharia Agricola e Ambiental, v.21, n.3, p.175-179, 2017. https://doi.org/10.1590/1807-1929/agriambi.v21n3p175-179

MARCHI, J.L.; GOMES-JUNIOR, F.G. Use of image analysis techniques to determine the embryo size of Senna multijuga (Rich.) seeds and its relation to germination and vigor. Journal of Seed Science, v.39, n.1, p.13-19, 2017. https://doi.org/10.1590/23171545v39n1165423

MARTINOVIC, T.; CIRIC, D.; PANTIC, I.; LALIC, K.; RASULIC, I.; DESPOTOVIC, S.; LALIC, I.; DJURICIC, D.; BUMBASIREVIC, V.; KRAVICSTEVOVIC, T. Unusual shape and structure of lymphocyte nuclei is linked to hyperglycemia in type 2 diabetes patients. Tissue and Cell, v.52, p.92-100, 2018. https://doi.org/10.1016/j.tice.2018.04.005

MARTINS, R.F.A.; SOUZA, A.F.C.; PITOL, C.; FALQUETO, A.R. Physiological responses to intense water deficit in two genotypes of crambe (Crambe abyssinica Hochst.). Australian Journal of Crop Science, v.11, n.7, p.821-827, 2017. https://doi.org/10.21475/ ajcs.17.11.07.pne469

MEDEIROS, A.D.; PEREIRA, M.D. SAPL': a free software for determining the physiological potential in soybean seeds. Pesquisa Agropecuária Tropical, v.48, n.3, p.222-228, 2018. https://doi.org/10.1590/1983-40632018v4852340

MEDEIROS, A.D.; ARAÚJO, J.O.; ZAVALA-LEÓN, M.J.; SILVA, L.J.; DIAS, D.C.F.S. Parameters based on x-ray images to assess the physical and physiological quality of Leucaena leucocephala seeds. Ciência e Agrotecnologia, v.42, n.6, p.643-652, 2018. https:// doi.org/10.1590/1413-70542018426023318

NOGUEIRA-FILHO, F.P.; OLIVEIRA, A.B.; PEREIRA, M.S.; LOPES, M.F.Q.; SILVA, R.T. Effectivity of $x$-ray test to evaluate the physiological quality of sesame seeds due to fruits position at the plant. Revista Brasileira de Ciências Agrárias, v.12, n.4, p.435-440, 2017. https://doi.org/10.5039/agraria.v12i4a5474

NORONHA, B.G.; MEDEIROS, A.D.; PEREIRA, M.D. Avaliação da qualidade fisiológica de sementes de Moringa oleifera Lam. Ciência Florestal, v.28, n.1, p.393-402, 2018. https://doi.org/10.5902/1980509831615.

PRADO-ALVES, M.V.; VON PINHO, É.V.R.; SANTOS, H.O.; PRADO-ALVES, G.C.; CARVALHO, M.L. M.; BUSTAMANTE, F.O. Image analysis, quality and maturation of jiló (Solanum gilo) seeds. Agrociencia, v.52, n.2, p.267-278, 2018. http://www.scielo.org.mx/scielo. php?script=sci_arttext\&pid=S1405-31952018000200267\&lng=es\&nrm=iso\&tlng=en

RANAL, M.A.; SANTANA, D.G.; FERREIRA, W.R.; MENDES-RODRIGUES, C. Calculating germination measurements and organizing spreadsheets. Revista Brasileira de Botânica, v.32, n.4, p.849-855, 2009. http://dx.doi.org/10.1590/S0100-84042009000400022

R Core Team 2019. R Development Core Team. A language and environment for statistical computing. 55: 275-286.

SAKO, Y.; MCDONALD, M.B.; FUJIMURA, K.; EVANS, A.F.; BENNETT, M.A. A system for automated seed vigour assessment. Seed Science and Technology, v.29, n.3, p.625-636, 2001.

SILVA, L.A.; SALES, J.D.F.; NEVES, J.M.G.; SANTOS, H.O.; SILVA, G.P. Radiographic image analysis of Anacardium othonianum Rizz (anacardiaceae) achenes subjected to desiccation. Acta Scientiarum, v.39, n.2, p.235-244, 2017. https://doi.org/10.4025/ actasciagron.v39i2.32484 
SILVA, L.J.; MEDEIROS, A.D.; OLIVEIRA, A.M.S. SeedCalc, a new automated R software tool for germination and seedling length data processing. Journal of Seed Science, v.41, n.2, p.250-257, 2019. https://doi.org/10.1590/2317-1545v42n2217267

SILVA, M.A.P.; LIMA, J.J.P.; BIAGGIONI, M.A.M.; CAVARIANI, C.; FERREIRA, G. Seed quality of crambe (Crambe abyssinica Hochst) submitted to different drying methods. Revista Ciência Agronômica, v.47, n.2, p.358-365, 2016. https://doi.org/10.5935/18066690.20160042

SILVA, V.N.; SARMENTO, M.B.; SILVEIRA, A.C.; SILVA, C.S.; CICERO, S.M. Avaliação da morfologia interna de sementes de Acca sellowiana O. Berg por meio de análise de imagens. Revista Brasileira de Fruticultura, v.35, n.4, p.1158-1169, 2013. http://dx.doi. org/10.1590/S0100-29452013000400027

SIMAK, M. Testing of forest tree and shrub seeds by X-radiography. In: GORDON, A.G.; GOSLING, P.; WANG, B.S.P. (Ed.) Tree and shrub seed handbook. Zurich: ISTA, 1991. p.1-28.

SOARES, T.F.S.N.; FREITAS, B.A.L.; FERREIRA-FILHO, J.G.A.; DIAS, D.C.F.S.; FIALHO, C.A.; MEDEIROS, A.D.; OLIVEIRA, R.M.; OLIVEIRA, A.S. Assessment of seed vigor tests for Crambe abyssinica. Journal of Agricultural Science, v.10, n.12, p.527-533, 2018. http:// dx.doi.org/10.5539/jas.v10n12p527

SOLTYS, Z.; ORZYLOWSKA-SLIWINSKA, O.; ZAREMBA, M.; ORLOWSKI, D.; PIECHOTA, M.; FIEDOROWICZ, A.; JANECZKO, K.; ODERFELDNOWAK, B. Quantitative morphological study of microglial cells in the ischemic rat brain using principal component analysis. Journal Neurosci Methods, v.146, n.1, p.50-60, 2005. http://dx.doi.org/10.1016/j.jneumeth.2005.01.009

TOLEDO, M.Z.; TEIXEIRA, R.N.; FERRARI, T.B.; FERREIRA, G.; CAVARIANI, C.; CATANEO, A.C. Physiological quality and enzymatic activity of crambe seeds after the accelerated aging test. Acta Scientiarum, v.33, n.4, p.687-694, 2011. http://dx.doi.org/10.4025/ actasciagron.v33i4.8248

XIA, Y.; XU, Y.; LI, J.; ZHANG, C.; FAN, S. Recent advances in emerging techniques for non-destructive detection of seed viability: a review. Artificial Intelligence in Agriculture, v.1, p.35-47, 2019. https://doi.org/10.1016/j.aiia.2019.05.001 use, distribution, and reproduction in any medium, provided the original work is properly cited. 